\title{
The enhancement of mathematical problem solving ability and self-confidence of students through problem based learning
}

\author{
Rahmi Ramadhani \\ Universitas Potensi Utama. Jalan K.L.Yos Sudarso KM 6,5 No. 3-A Kota Medan, 20241, Indonesia. \\ * Corresponding Author. Email: rahmiramadhani3@gmail.com \\ Received: 8 March 2017; Revised: 16 May 2018; Accepted: 5 June 2018
}

\begin{abstract}
This paper reported result of a research attempted to analyze: the increase in student's MPS and SC using problem-based learning; and to look interaction between students' PMK and learning to increase student's MPS and SC. This type of research was a quasi-experimental. The population of this research was all students in SMA Negeri 6 Medan. Then 33 students were chosen as the experimental class and 33 students in other class was chosen as a control class by using purposive sampling technique. The data in this study were analyzed using Two Ways ANOVA. The result of validity of student's MPS test is 0,808 . Both reability of test was 0.86 . The result of this research were: (1) The enhancement of student's MPS ability and SC using problem-based learning was higher than conventional learning; (2) There is no interaction between student's PMK and learning on student's MPS ability and SC.
\end{abstract}

Keywords: mathematical problem solving ability, problem-based learning, self-confidence

How to Cite: Ramadhani, R. (2018). The enhancement of mathematical problem solving ability and selfconfidence of students through problem based learning. Jurnal Riset Pendidikan Matematika, 5(1), 127-134. doi:http://dx.doi.org/10.21831/jrpm.v5i1.13269

Permalink/DOI: http://dx.doi.org/10.21831/jrpm.v5i1.13269

\section{INTRODUCTION}

Mathematics in the view of philosophy are (a) human activities involving solutions of the problem; (b) the math problems and solutions are divided into the specific sections or collectives in studying the problem; (c) mathematics is a symbolic language in which the problems and solutions will be presented systematically; and (d) mathematics is an organized logical conceptual system (Ernest, 2013, p.25). Tymoczko (1998, p.8) also states that the philosophy of mathematics begins when how we use mathematics in solve the problems in daily life. The National Council of Teachers of Mathematics (Gordah \& Astuti, 2013, p.228) formulates the goals of mathematics learning: (1) learning to communicate (mathematical communication); (2) learning to reason (mathematical reasoning); (3) learning to solve the problems (mathematical problem solving); (4) learning to connect ideas (mathematical connections); and (5) the formation of positive attitude toward mathematics (positive attitudes toward mathematics).
As we know, the students' mathematical skill in Indonesia is still low. Research by TIMSS 2007, TIMSS 2011 and PISA 2009; found that the Indonesian students have low ability to answer the mathematical questions of international standards, especially on mathematical problem solving (Pure, Sabandar, Kusumah \& Kartasamita, 2013, p.194). Herman support the report by TIMSS, states that the problem solving abilities of Junior High School students is relatively better in problem solving of procedure task, but they are very weak in solve the non-routine problems and problem-solving (Fauziah, 2010, p. 2).

The Problem solving ability is the students' ability to solve math problems by observing the process of finding answers based on problem-solving steps (understanding problems, planning to solve the problem, solving problems and re-checking) proposed by polya (Nurdalilah, Syahputra, \& Armanto, 2013, p.117). Branca states that, the problem-solving ability is the heart of mathematics (Effendi, 2012, p.2). The ability of problem-solving is important in mathematics, not only for those who will learn 
or study mathematics, but also for those who will apply them in many fields of daily life (Effendi, 2012, p.3). Based on these findings, the problem-solving ability must be possessed by students to train them to be familiar with problems, either in math or other areas of study, moreover, to apply to solve the complex problems in daily life.

Another reason for low of students' learning outcome is low of students' confidence in solving the math problems. Self-confidence is one's belief on their ability to improve the performance and it affects to their daily life (Bandura, 1995, p.2). Self-confidence is essential for students to be succeeded in learning math (Martyanti, 2016, p.16). With selfconfidence, the students will be more motivated and like to learn math, in the last, it hoped the achievement or learning outcome of mathematics is also optimal. Supported by previous studies, it revealed the positive association between self-confidence in learning mathematics and mathematics learning outcomes (Hannula, Maijala, \& Pehkonen, 2004, p.17; Mullis, Martin, Foy, \& Arora, 2012, p.326; Suhendri, 2012, p.397). Means, the high learning outcome of mathematic is for students who have high self-confidence index. Therefore, confidence must be possessed and developed within student.

In fact, the need of self-confidence within students in learning mathematics is not supported by the facts in the field. There are number of students who have low of self-confidence. It revealed in a study by Mullis et al. (2012, p.338) which states on the level of students' selfconfidence in Indonesia, is presented in Figure 1.

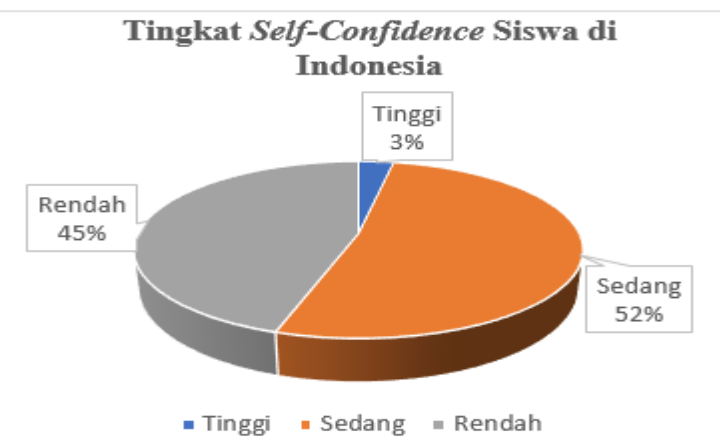

Figure 1. Level of students' Self-Confidence in Indonesia

Also, supported by research conducted by Hanulla (Wijayanti, 2013, p.192) on Development of Understanding and Self-Confidence in Mathematics; grades 5-8. The findings showed that there is a strong relationship between selfconfidence and mathematical achievement. Based on previous background, the particular article tried to increase the students' selfconfidence, especially students' on Senior High School. A number of ways might be performed to improve the students' self-confidence, such through the implementation of mathematical learning model.

There many researchers have conducted study aiming to improve the students' mathematical ability, especially on problem solving and students' self-confidence. Lousiell and Descamps (Trianto, 2010, p.57), used cooperative learning of jigsaw to develop the skills in finding the concepts and problem-solving skills. Effendi (2012, p.1) used guided discovery learning in improving the representation and problem solving skills of high school students. Chapman (2005, p.255) used a reflective-inquiry approach to improve self-awareness and problems solving. And research conducted by Surya, Sabandar, Kusumah, \& Darhim (2013, p.11), used Contextual Teaching Learning to improve the ability of visual thinking, representation and problem solving.

Based on the previous research descripttion, problem-based learning (PBM) is one of the learning models that can improve higher order thinking skills. PBM is a learning model that uses problems as foundation in teaching learning (Napitupulu, Suryadi, \& Kusumah, 2016, p. 119). In problem-based learning, students are grouped into groups' discussion, then they are given worksheet containing non routine problem and discuss it. The students make collaboration to solve the problem. Teachers perform their roles to facilitate the learning through scafolding techniques by providing direct guidance or asking stimulus questions to assist the students in looking for possibity ways to find the final solutions of the mathematical problems through the students' daily experiences (Napitupulu et al., 2016 , p 119).

The syntaxs of PBM are (1) studentorientation on the problem; (2) organize the students to learn; (3) guide an individual and group investigation; (4) develop and display the work; and (5) analyze and evaluate the problemsolving process (Trianto, 2010, p 98). Based on the PBM syntax explanation, it hoped to give a significant contribution in improving the problem solving ability and self-confidence of students, especially on students of grade-9 Senior High School. 


\section{METHOD}

\section{Research Method}

This type of research was a quasi-experiment. The independent variables were problembased learning and conventional learning. The dependent variables were problem-solving of mathematical and self-confidence after treatment. The control variable was the Initial Mathematical Ability (KAM) of students and classified into three categories: high, medium, and low. The research design was pretestposttest control group design. There two groups were selected randomly for experimental class and control class.

\section{Population and Sample}

The population of this research was all students in SMA Negeri 6 Medan. Then 33 students of science class 1 were chosen as the experimental class and 33 students in other class was chosen as a control class by using purposive sampling technique. The entire classes were given the same learning materials ie the rule of sine, cosine and the area of the triangle. Those materials involved in the mathematics learning material of grade 9 according to the 2013 curriculum.

\section{Research Procedures}

This research used quasi-experiment design with pretest-posttest group. This research used two classes; experimental class (treated by problem based learning) and control class (not treated). Both classes had the pretest and posttest, and self-confidence questionnaire. It had purpose to know the significant increasing toward the development of students' mathematical problem-solving ability and self-confidence before and after the treatment.

\section{Data, Instrument and Data Collection}

The study consisted of two types of instruments: quantitative and qualitative. Mathematical problem solving ability tests (KPMM), initial mathematical ability data (KAM) and scale of self-confidence (SC), those were quantitative data. Observation on learning process and students' response to learning were qualitative data.

The SC Scale consisted of 20 valid items consisting of five answer choices: strongly agree (SS), agree (S), less disagree (KS), disagree (TS) and strongly disagree (STS). The item of SC statement consisted of five indicators: self- esteem, optimistic, objective, responsible, and rational and realistic. Reliability of SC scale was on high category. The KPMM test consisted of 5 question items of medium and difficult level. The KPMM test indicators were: understanding the problem, planning the problem solving, implementing the plan of problem solving and re-examine.

Before the use of research instrument, performed an instrument validation stage. The validation stage is conducted by giving tests to the students of non-research sample. Then, it continued to perform the calculation by validity test item with the formula of Pearson Product Moment correlation. After obtained valid instruments, the instruments were ready to use. The data in this study were analyzed using Two Ways ANOVA

\section{Data Analysis Technique}

The data were analyzed using T-Test, One Way ANOVA and Two Ways ANOVA. All statistical tests used significant values below 0.05 . The Software of SPSS version 17 and Microsoft Excel were used in entire test.

\section{RESULT AND DISCUSSION}

\section{Mathematical Problem Solving Ability (KPMM)}

Table 1 presents general information on student KPMM according to the factors. Overall or according to the student's KAM (Initial Ability Mathematical) category, experimental groups (treated using problem-based learning) gained better results than control group (treated using conventional learning). Based on the result of data calculation using Kolmogorof-Smirnov Test and Leneve's Test, showed the samples were normally distributed and had homogeneous variance.

Table 1. Description of KPMM

\begin{tabular}{ccccccc}
\hline & N & Min & Max & $\overline{\boldsymbol{X}}$ & SD & Var \\
\hline Pretest_Experiment & 33 & 6.0 & 12.0 & 8.36 & 1.61 & 2.59 \\
\hline Posttest_Experiment & 33 & 13.0 & 19.0 & 15.5 & 1.61 & 2.59 \\
\hline Pretest_Control & 33 & 5.5 & 10.5 & 8.29 & 1.26 & 1.59 \\
\hline Posttest_Control & 33 & 11.5 & 18.0 & 14.0 & 1.62 & 2.63 \\
\hline
\end{tabular}

Table 2 and Table 3 present description of KPMM data based on $\mathrm{N}$-Gain score seen from the student group and KAM group of students. 
Table 2. Description of KPMM Based on NGain Each Learning

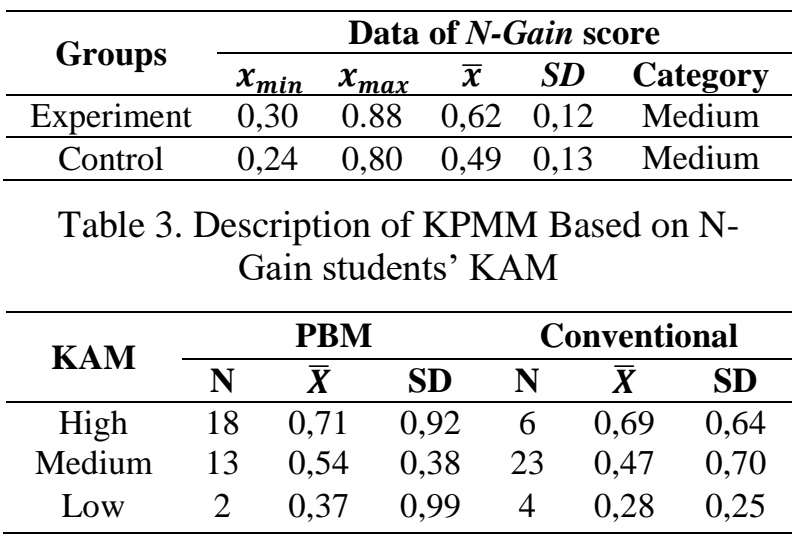

After pretest and posttest, it obtained NGain on each class to know the increasing KPMM between students in control class and students in experimental class. The average score of N-Gain KPMM in experimental class is 0.62 and in control class is 0.49 .

The test result of Two Ways ANOVA, and N-Gain KPMM of experiment and control group, are presented in Table 4.

Table 4. Test Result of KPMM Hypothesis Using Two Ways ANAVA

\begin{tabular}{|c|c|c|c|c|c|}
\hline \multicolumn{6}{|c|}{ Tests of Between-Subjects Effects } \\
\hline \multicolumn{6}{|c|}{ Dependent Variable:NGain_KPMM } \\
\hline Source & $\begin{array}{l}\text { Type III Sum } \\
\text { of Squares }\end{array}$ & & $\begin{array}{l}\text { Mean } \\
\text { Square }\end{array}$ & $\mathrm{F}$ & \\
\hline Corrected Model & $1.067^{\mathrm{a}}$ & 5 & .213 & 42.242 & .000 \\
\hline Intercept & 8.570 & 1 & 8.57 & 1695.7 & .000 \\
\hline Learning & .028 & & .028 & 5.537 & .022 \\
\hline KAM & .742 & 2 & .371 & 73.366 & .000 \\
\hline Learning * KAM & .011 & & .006 & 1.117 & .334 \\
\hline Error & .303 & 60 & .005 & & \\
\hline Total & 21.678 & 66 & & & \\
\hline Corrected Total & 1.371 & 65 & & & \\
\hline
\end{tabular}

a. $\mathrm{R}$ Squared $=, 779$ (Adjusted R Squared $=, 760$ )

Based on Table 4, on the learning factor, obtained the F score is 5.537 and the significant score is 0.022 . Because the significant score is smaller than the significant level of 0.05 , then $\mathrm{H}_{0}$ is rejected and $\mathrm{H}_{1}$ is accepted. In sum, concluded that, the improvement of students' KPMM who obtained problem-based learning is higher than the students' KPMM who obtained conventional learning.
Estimated Marginal Means of NGain_KPMM

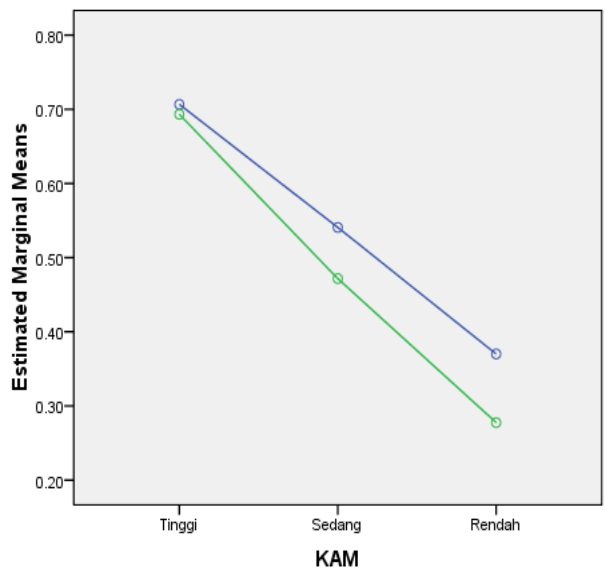

Pembelajaran 二Eksperimen

Figure 2. Interaction between students' KPMM and KAM

Table 4 shows the learning factor and KAM, gained the F score is 1.117 and the significant score is 0.334 . Because the significant score is higher than the significance level of 0.05 , then $\mathrm{H}_{1}$ is rejected and $\mathrm{H}_{0}$ is accepted. Thus, concluded that there is no significant interaction between learning with KAM toward the increasing score of students' KPMM. It proved that the average score of students' KPMM with KAM (high, medium, and low), students who taught by problem-based learning did not show significant differrence with students who taught by conventional learning. The interaction test graph is presented in Figure 2.

Figure 3 shows the improvement of student KPMM based on KPMM indicators and student learning groups.

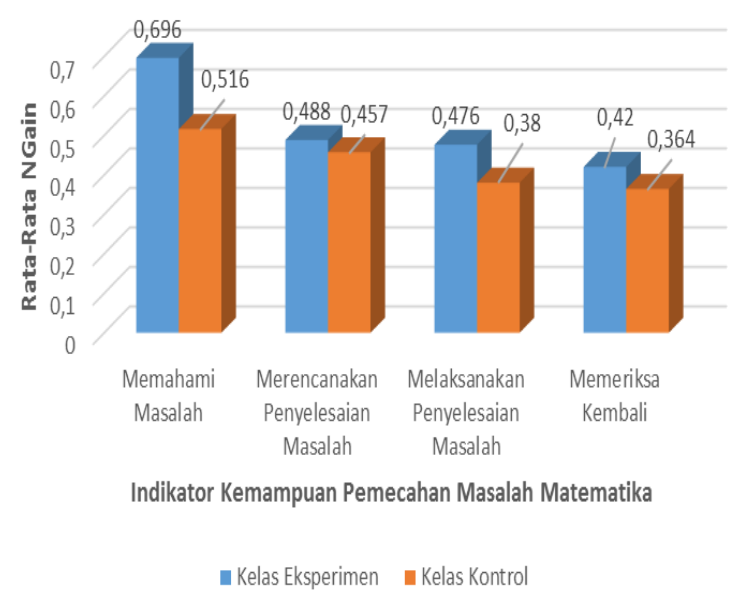

Figure 3. The KPMM Improvement based on KPMM Indicators

Based on Figure 3, the students who gained problem-based learning, they gained higher score improvement of KPMM on 
indicators of understanding the problem (0.696) than conventional learning (0.516). In control class, the highest improvement also occurred on indicators of understanding the problem is (0.516). The smallest improvement scores of problem-based learning and convention are on the indicator of checking; 0.42 (problem-based learning) and 0.364 (conventional learning)

\section{Self-Confidence}

Table 5 presents the mean data descriptions of SC both in the learning groups (problem-based learning and conventional learning).

Table 5. Description of SC

\begin{tabular}{lccccc}
\hline & N Min & Max & Mean & SD \\
\hline Pretest_Experiment & 33 & 54 & 83 & 67.67 & 8.11 \\
\hline Posttest_Experiment & 33 & 80 & 98 & 90.51 & 4.54 \\
\hline Pretest_Control & 33 & 50 & 68 & 60.09 & 4.53 \\
\hline Posttest_Control & 33 & 78 & 88 & 80.97 & 2.92 \\
\hline
\end{tabular}

Table 6 and Table 7 present the descriptions of SC questionnaire data based on $\mathrm{N}$-Gain score seen from the student group and KAM group of students.

Table 6. Description of SC Questionnaire Based on N-Gain Each Learning

\begin{tabular}{cccccc}
\hline \multirow{2}{*}{ Groups } & \multicolumn{5}{c}{ Data of $\boldsymbol{N}$-Gain score } \\
\cline { 2 - 6 } & $\boldsymbol{x}_{\min }$ & $\boldsymbol{x}_{\max }$ & $\overline{\boldsymbol{x}}$ & $\boldsymbol{S D}$ & Category \\
\hline Experiment & 0,33 & 0,69 & 0,40 & 0,08 & Medium \\
\hline Control & 0,24 & 0,50 & 0,31 & 0,07 & Medium \\
\hline
\end{tabular}

Table 7. Deskripsi Angket SC Berdasarkan NGain dan KAM Siswa

\begin{tabular}{ccccccc}
\hline \multirow{2}{*}{ KAM } & \multicolumn{3}{c}{ PBM } & \multicolumn{4}{c}{ Conventional } \\
\cline { 2 - 7 } & $\mathbf{N}$ & $\overline{\boldsymbol{x}}$ & SD & $\mathbf{N}$ & $\overline{\boldsymbol{x}}$ & SD \\
\hline High & 18 & 64,83 & 6,58 & 18 & 88,89 & 5,18 \\
\hline Medium & 13 & 71,61 & 8,54 & 13 & 92,85 & 2,67 \\
\hline Low & 2 & 67,50 & 12,02 & 2 & 90,00 & 4,54 \\
\hline
\end{tabular}

After pretest and posttest, it obtained NGain on each class to know the increasing SC between students in control class and students in experimental class. The average score of $\mathrm{N}-$ Gain $\mathrm{SC}$ in experimental class is 0.40 and in control class is 0.31 .

The results of the calculation of Two Ways ANAVA, N-Gain SC of experimental and control class are presented in Table 8. Based on Table 8 , on the learning-learning factor, the $\mathrm{F}$ score is 94,863 and the significant score is 0.000 . Because the significant score is smaller than the significance level of 0.05 , then $\mathrm{H}_{0}$ is rejected and $\mathrm{H}_{1}$ is accepted. Thus, concluded that there is significant improving of students' SC on students' who taught by problem-based learning than conventional learning.

Based on Table 8, the learning factor and $\mathrm{KAM}$, it obtained the F score is 0.395 and significant score is 0.675 . Because the significant score is higher than the significance level of 0.05 , then $\mathrm{H}_{1}$ is rejected and $\mathrm{H}_{0}$ is accepted. Thus, concluded that there is no significant interaction between learning with KAM toward the increasing of students' SC. It proved that the average score of students' SC with KAM (high, medium, and low), students who taught by problem-based learning did not show significant differrence with students who taught by conventional learning. The interaction test graph is presented in Figure 4.

Table 8. Test Results of Hypothesis SC Using Two Ways ANAVA

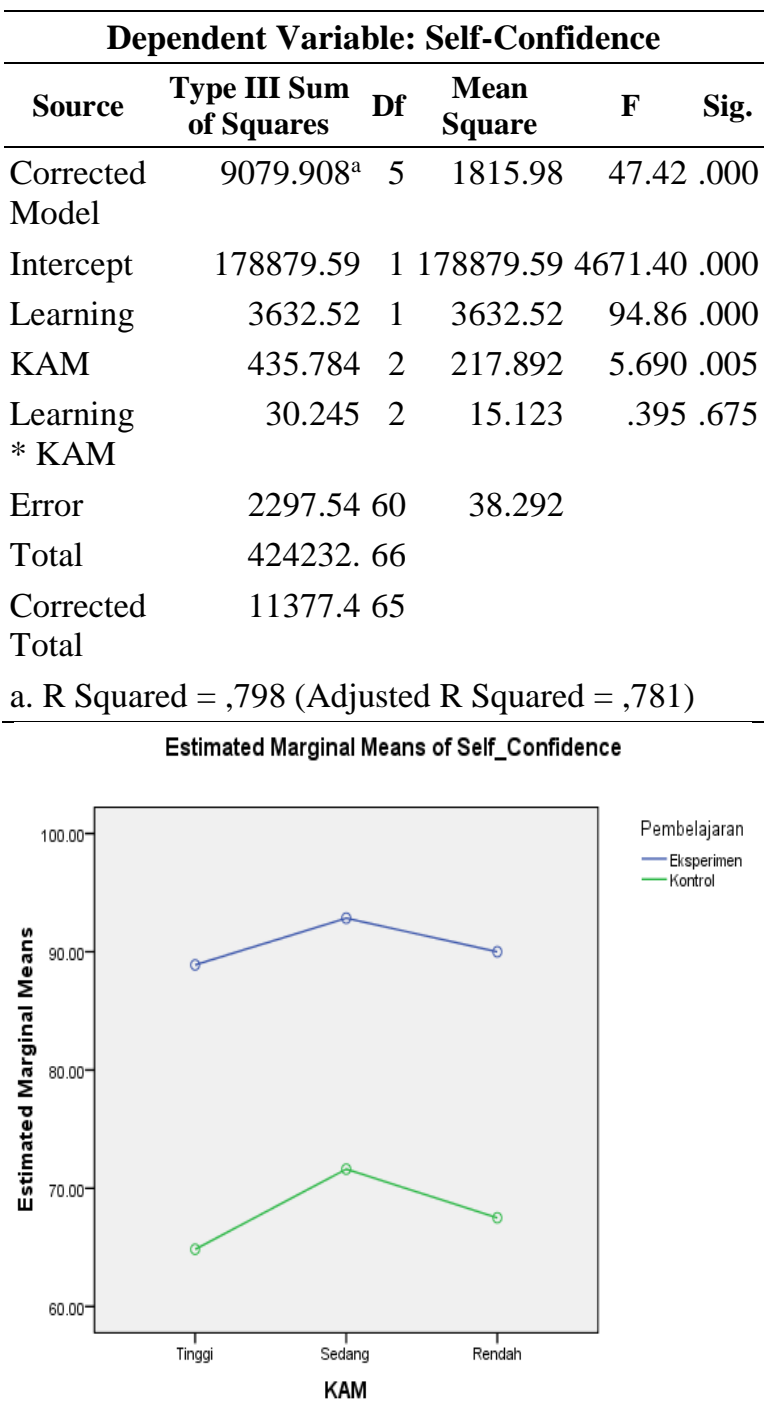

Figure 4. Interaction between SC and KAM 
Based on Figure 2 and Figure 4, show that there is no interaction between learning and KAM toward SC. However, it is interesting, the $\mathrm{SC}$ in medium of KAM have a higher questionnaire score than the SC scores in high and low KAM in experimental class (treated by problembased learning). The same fact also occurs on control class (treated by conventional learning). The SC questionnaire scores in medium of KAM have higher questionnaire scores than the SC scores in high and low KAM.

Based on previous discussion, concluded that the students who taught with problem-based learning more treated in improving the KPMM and SC because the average score in the experimental class is higher than the average score in the conventional class. In sum, there is no interaction between learning with KAM toward the improving of KPMM and SC students.

The findings is in line with the statement by Mellin-Olsen (Ernest, 2013, p 245), states: "increasingly acknowledged that the cognitive level of student response in mathematics is determined not by the 'ability' of the student, but the skill with which the teacher is able to engage the student in mathematical 'activity'". Based on the statement, concluded that the cognitive level of students in mathematics is not determined by the ability of students, but the skills with which by teachers is able to engage the students in mathematics activities. Moreover, problembased learning is also supported by constructivism theory. The theory of constructivism that supported by the theory of (Perkins, Piaget, and Vygotsky) explains that individuals can build knowledge through their environment. In short, through investigation, conversation, or activity, a student can build a new knowledge by build their current knowledge (Grant, 2002, p 2).

The similar results of previous studies, such as a research conducted by (Ajai, Imoko, \& O'kwu, 2013, p. 131) showed that the students who taught using problem-based learning has higher of final score test than those who taught using conventional learning. Another similar results also found by Khoiriyah, AminFauzi, \& Syahputra (2014), stated that the students' problem solving skills who use problem-based learning is higher to improve than the students who use conventional learning.

\section{CONCLUSION}

Aiming to improve the students' ability of mathematical problem solving and self-confi- dence in the learning process in school, it requires a high commitment both students and teachers. Another very important thing is the implementation of learning models that is able to engage the students in learning process. The student contributions occur through group investigation dan discussion activities. Group investigation aims to create a meaningful learning atmosphere and improve the students' selfconfidence, especially in the process of solving the mathematical problems.

The collaboration among students, teachers and appropriate learning model can create aconducive learning atmosphere, and with which athmosphere is able to improve the students' mathematical abilities, such mathematical problem solving ability. Not only cognitive factors of students to develop, but the affective factors of students can also develop such students' self-confidence.

\section{REFERENCES}

Ajai, J. T., Imoko, B. I., \& O’kwu, E. I. (2013). Comparison of the learning effectiveness of problem-based learning (PBL) and conventional method of teaching algebra. Journal of Education and Practice, 4(1), 131-135. Retrieved from http://www.iiste.org/Journals/index.php/J EP/article/view/4053

Bandura, A. (1995). Self-efficacy in changing societies. Cambridge, MA: Cambridge University Press.

Chapman, O. (2005). Constructing pedagogigal knowledge of problem solving: Preservice mathematics teachers. In International Group for the Psychology of Mathematics Education (Vol. 2, pp. 225-232). Cape Town: International Group for the Psychology of Mathematics Education. 35 Aandwind Street, Kirstenhof, Cape Town, 7945, South Africa. Tel: +27-21-7153559; Fax: +27-88-021-715-3559; e-mail: info@igpme.org; Web site: http://igpme.org. Retrieved from http://igpme.org

Effendi, L. A. (2012). Pembelajaran matematika dengan metode penemuan terbimbing untuk meningkatkan kemampuan representasi dan pemecahan masalah matematis siswa SMP. Jurnal Penelitian Pendidikan, 12(2). Retrieved from http://jurnal.upi.edu/penelitianpendidikan/view/1852/pembelajaran- 
matematika-dengan-metode-penemuanterbimbing-untuk-meningkatkankemampuan-representasi-dan-pemecahanmasalah-matematis-siswa-smp.html

Ernest, P. (2013). Philosophy Mathematics Educ. Routledge.

Fauziah, A. (2010). Peningkatan kemampuan pemahaman dan pemecahan masalah matematik siswa SMP melalui strategi react. Forum Kependidikan, 30(1), 1-13. Retrieved from http://forumkependidikan.unsri.ac.id/userf iles/ANA FAUZIAH.pdf

Gordah, E. K., \& Astuti, R. (2013). Meningkatkan kemampuan komunikasi matematis siswa melalui pengembangan bahan ajar geometri dasar berbasis model recipcoral teaching di STKIP PGRI Pontianak. In Seminar Nasional Matematika dan Pendidikan Matematika 2013. Yogyakarta: Jurusan Pendidikan Matematika FMIPA UNY. Retrieved from http://eprints.uny.ac.id/10752/

Grant, M. M. (2002). Getting a grip on projectbased learning. Meridian: A Middle School Computer Technologies Journal, 5(1). Retrieved from https://projects.ncsu.edu/meridian/win200 2/514/

Hannula, M. S., Maijala, H., \& Pehkonen, E. (2004). Development of understanding and self-confidence in mathematics; Grades 5-8. In International Group for the Psychology of Mathematics Education. Bergen, Norway: International Group for the Psychology of Mathematics Education, 35 Aandwind Street, Kirstenhof, Cape Town, 7945, South Africa. Web site: http://igpme.org.

Khoiriyah, D., AminFauzi, K. M., \& Syahputra, E. (2014). Peningkatan kemampuan pemecahan masalah matematika dan selfefficacy siswa melalui pembelajaran berbasis masalah di MAN 1 Padangsidimpuan. Paradikma Jurnal Pendidikan Matematika, 7(2), 30. Retrieved from http://jurnal.unimed.ac.id/2012/index.php/ paradikma/article/view/2959

Martyanti, A. (2016). Keefektifan pendekatan problem solving dengan setting STAD dan TAI ditinjau dari prestasi dan selfconfidence. Jurnal Riset Pendidikan
Matematika,

$3(1)$ $1-15$. https://doi.org/10.21831/jrpm.v3i1.9825

Mullis, I. V. S., Martin, M. O., Foy, P., \& Arora, A. (2012). TIMSS 2011 international result in mathematics. Boston, MA: TIMSS \& PIRLS International Study Center. Retrieved from https://timssandpirls.bc.edu/timss2011/do wnloads/T11_IR_Mathematics_FullBook. pdf

Murni, A., Sabandar, J., Kusumah, Y. S., \& Kartasamita, B. G. (2013). The enhancement of junior high school students' abilities in mathematical problem solving using soft skill-based metacognitive learning. Journal on Mathematics Education, 4(2), 194-203. https://doi.org/10.22342/jme.4.2.554.194203

Napitupulu, E. E., Suryadi, D., \& Kusumah, Y. S. (2016). Cultivating upper secondary students' mathematical reasoning -ability and attitude towards mathematics through problem-based learning. Journal on Mathematics Education, 7(2), 117-128. https://doi.org/10.22342/jme.7.2.3542.117 $-128$

Nurdalilah, N., Syahputra, E., \& Armanto, D. (2013). Perbedaan kemampuan penalaran matematika dan pemecahan masalah pada pembelajaran berbasis masalah dan pembelajaran konvensional di SMA Negeri 1 Kualuh Selatan. Paradikma Jurnal Pendidikan Matematika, 6(2), 30. Retrieved from http://jurnal.unimed.ac.id/2012/index.php/ paradikma/article/view/1056

Suhendri, H. (2012). Pengaruh kecerdasan matematis-logis, rasa percaya diri dan kemandirian belajar terhadap hasil belajar matematika. In Seminar Nasional Matematika dan Pendidikan Matematika 2012. Yogyakarta: Jurusan Pendidikan Matematika Fakultas Matematika dan Ilmu Pengetahuan Alam, Universitas Negeri Yogyakarta. Retrieved from http://eprints.uny.ac.id/8082/

Surya, E., Sabandar, J., Kusumah, Y. S., \& Darhim, D. (2013). Improving of junior high school visual thinking representation ability in mathematical problem solving by CTL. Journal on Mathematics Education, $\quad 4(1), \quad 113-126$. 
Jurnal Riset Pendidikan Matematika, 5 (1), 2018 - 134

Rahmi Ramadhani

https://doi.org/10.22342/jme.4.1.568.113126

Trianto, T. (2010). Mendesain model pembelajaran inovatif-progresif: konsep, landasan, dan imlementasinya pada kurikulum tingkat satuan pendidikan (KTSP). Jakarta: Kencana.

Tymoczko, T. (1998). New directions in the philosophy of mathematics: An anthology.
Princeton University Press.

Wijayanti, P. S. (2013). Pengaruh pendekatan MEAs terhadap kemampuan pemecahan masalah, komunikasi matematis, dan kepercayaan diri siswa. Pythagoras: Jurnal Pendidikan Matematika, 8(2), 181-192.

https://doi.org/10.21831/PG.V8I2.8948 